\title{
EVALUASI DAN PERUMUSAN REKOMENDASI SENAYAN LIBRARY MANAGEMENT SYSTEMS PERPUSTAKAAN MENGGUNAKAN FRAMEWORK COBIT4.1
}

\author{
Lilis Aminawati ${ }^{1)}$; Sri Siswanti ${ }^{\left.2^{*}\right)}$; Setyowati ${ }^{3)}$ \\ ${ }^{1)}$ Program Studi Sistem Informasi, STMIK Sinar Nusantara Surakarta \\ ${ }^{2)}$ Program Studi Teknik Informatika, STMIK Sinar Nusantara Surakarta \\ ${ }^{3)}$ Program Manajemen Informatika , STMIK Sinar Nusantara Surakarta \\ ${ }^{1)}$ lilisaminawati29@ gmail.com; 2) sy swanty @ sinus.ac.id; ${ }^{3)}$ setiy owati.zaini@ gmail.com
}

\begin{abstract}
Senayan Library Management Systems (SLiMS) is a licensed open source library management system software under the GPLv3. Evaluation of the system process needs to be done especially on the data storage and data processing since both are important in managing data in the library of STIE AUB of Surakarta. The purpose of this study is to determine the maturity level of Senayan Library Management Systems (SLiMS) and provide system recommendation using the domain of Delivery and Support 1 (DS1) and Delivery Support 11 (DS11) with COBIT Framework 4.1. The methods used were observation, interview, literature study and questionnaire. The questionnaires were given directly to the respondents related to the system users, and the performance of the system was carried out by using maturity levels to produce recommen dations at the library of STIE AUB Surakarta.
\end{abstract}

Keywords : Senayan Library Management Systems, COBIT 4.1, Domain DS1, DS11, Maturity Level

\section{PENDAHULUAN}

Perpustakaan merupakan salah satu faktor penting pada lembaga pendidikan yang dapat mendukung peningkatan prestasi dan kualitas mahasiswa, peningkatan kegiatan belajar mengajar serta peningkatan mutu lembaga pendidikan tersebut.

Kehadiran Teknologi Informasi telah memudahkan perpustakaan dalam melakukan berbagai macam kegiatan-kegiatan yang menyangkut tugas dan fungsi perpustakaan.

Dalam mengikuti era Teknologi Informasi STIE AUB Surakarta menggunakan sistem informasi yang digunakan untuk mengelola manajemen perpustakaan yaitu Senayan Library Management Systems (SLiMS). Senayan Library Management System (SLiMS) merupakan sebuah perangkat lunak sistem manajemen perpustakaan bersifat terbuka, bersifat open source yang bisa dikembangkan sesuai kebutuhan, dibangun dengan menggunakan PHP, basis data MySQL dan pengontrol versi Git.

Pemanfaatan dari sistem informasi Senayan Library Management Systems (SLiMS) pada Perpustakaan STIE AUB Surakarta belum diketahui tingkat dari Maturity Level mengenai Deliver and Support 1 dan Deliver and Support 11 karena belum diketahui bagaimana mengidentifikasi atau mendefinisikan pelayanan, dan belum diketahui bagaimana tingkat dari Maturity Level untuk memanajemen pengolahan data sesuai dengan standart COBIT 4.1.

Hasil audit pada proses pengelolaan data atau manage data (DS11) menunjukkan tingkat kematangan satu (1) yakni berada pada tingkat awalinitial untuk sistem informasi DIGILIB saat ini (as is). Sedangkan tingkat kematangan yang diharapkan untuk proses DS11 adalah tingkat tiga (3) yakni proses terdefinisi/defined. Proses pengelolaan data masih belum diperhatikan dalam perkembangan DIGILIB saat ini. (Juliandarini \& Handayaningsih, 2013) 
Pada penelitian yang berjudul Audit Sistem Informasi Akademik Perguruan Tinggi (PT) XYZ Menggunakan Kerangka Kerja COBIT 4.1 dihasilkan bahwa PT XYZ baru mencapai maturity level 2 meskipun telah mengimplementasikan Sistem Informasi Akademik selama kurang lebih 6 tahun. Hal ini mengindikasikan bahwa perkembangan sistem berlangsung lambat dan perlu segera dilakukan inovasi perbaikan. (Satyareni \& Mahanani, 2014)

Berdasarkan permasalahan diatas maka dilakukan evaluasi senayan library management systems perpustakaan menggunakan framework COBIT4.1. Tujuannya adalah untuk mengukur tingkat kematangan sistem informasi Senayan Library Management Systems (SLiMS) pada Perpustakaan STIE AUB Surakarta, menggunakan kontrol proses Define and Manage Service Levels (DS1) dan Manage Data (DS11) sesuai framework COBIT 4.1 dan merumuskan rekomendasi yang dibutuhkan berdasarkan COBIT 4.1.

\section{TINJAUAN PUSTAKA}

COBIT adalah kerangka kerja tata kelola TI dan toolset pendukung yang memungkinkan manajer untuk menjembatani kesenjangan antara kebutuhan kontrol, masalah teknis dan risiko bisnis. COBIT memungkinkan pengembangan kebijakan yang jelas dan praktek yang baik untuk TI kontrol seluruh organisasi. COBIT menekankan kepatuhan pada peraturan, membantu organisasi untuk meningkatkan nilai yang diperoleh dari TI, memungkinkan penyelarasan dan menyederhanakan pelaksanaan kerangka kerja COBIT. (Meadwos Rolling, 2007)

Maturity level adalah suatu cara untuk mengukur bagaimana suatu proses manajemen telah dilakukan. Secara umum, maturity level berguna untuk memampukan perusahaan melakukan branch marking dan identifikasi pembaharuan yang dilakukan. Pada COBIT terdapat enam level penilaian seperti pada Gambar 1.

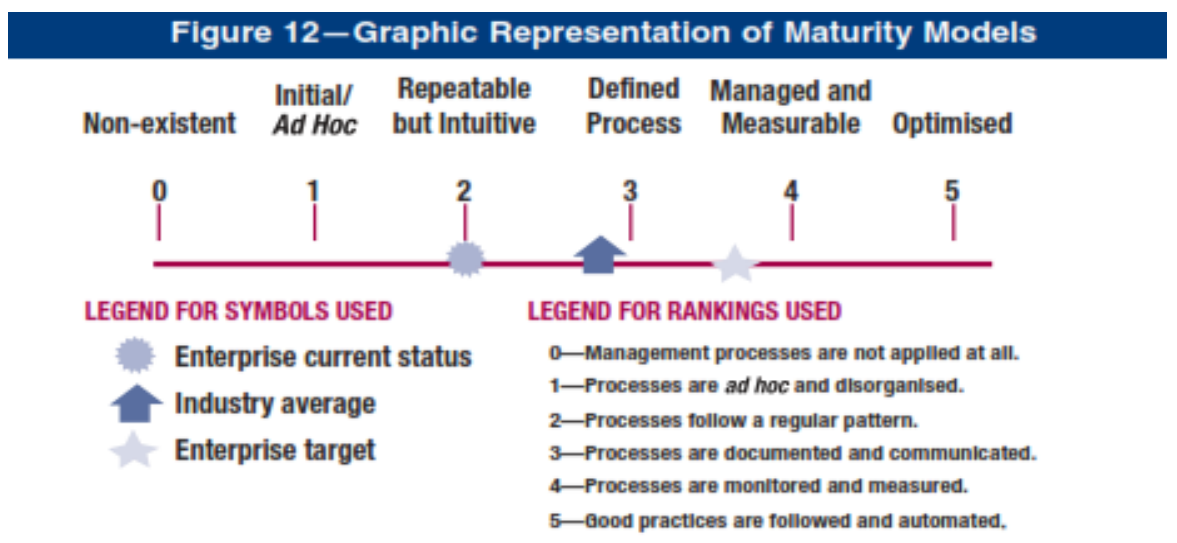

Gambar 1. Tingkat Maturity Model (Meadwos Rolling, 2007)

Maturity Model dibuat berdasarkan metode yang digunakan untuk mengevaluasi organisasi. Model ini merupakan metode skoring yang memungkinkan organisasi untuk memberikan peringkat atau ranking bagi dirinya sendiri, penilaian tersebut mulai dari 0 (non-existent) sampai dengan tingkat kematangan yang optimis atau 5 (optimized). Alat bantu pengukuran ini memberikan kemudahan untuk memahami bagaimana menentukan posisi organisasi saat ini (as-is) dan posisi ke depan (to-be) dengan mengacu pada best practice dan panduan standar yang ada. Maturity model dibuat berdasarkan model kualitatif (generic qualitative model), prinsip dari 6 (enam) atribut ditambahkan dengan cara bertingkat, enam atribut tersebut adalah: 
1. Kepedulian dan komunikasi (awareness and communication) - AC

2. Kebijakan, standar dan prosedur (policies, standards and procedure)- PSP

3. Perangkat bantu dan otomatisasi (tools and automation) - TA

4. Ketrampilan dan keahlian ( skills and expertise )- SE

5. Pertanggungjawaban internal dan eksternal (responsibility and accountability)- $R A$

6. Penetapan tujuan dan pengukuran (Goal setting and measurement)-GSM

Senayan Library Management Systems (SLiMS) merupakan salah satu Free Open Source Software (FOSS) digunakan untuk membangun aplikasi perpustakaan berbasis web. Aplikasi SLiMS dibangun dengan menggunakan PHP, basis data MySQL dan pengontrol versi Git. SLiMS mampu berjalan sempurna di dalam sistem jaringan intranet atapun internet. SliMS awalnya di produksi oleh Pusat Informasi dan Humas Departemen Pendidikan nasional yang dirintis oleh para developer yang hamper semuanya alumni jurusan Ilmu Perpustakaan Universitas terkemuka di Indonesia. Sebagai perangkat lunak otomatisasi perpustakaan, SliMS mampu mempermudah kegiatan manajemen administrasi perpustakaan. (Azwar, 2013)

Pada penelitian Juliandari Sri Handayingsih (2013) tentang Audit Sistem Informasi Pada Digilib Universitas XYZ menggunakan Kerangka Kerja Cobit 4.0. Pada proses manage performance and capacity (DS3) berada pada tingkat 2, sedangkan pada proses manage data (DS11) pada tingkat kematangan level 1. Rekomendasi berdasarkan laporan hasil audit, diharapkan mampu untuk memberikan solusi dalam penanganan pengelolaan kinerja dan kapasitas serta penanganan masalah pengelolaan data pada system informasi Digilib Universitas XYZ. (Juliandarini \& Handayaningsih, 2013)

Pada penelitian Lala Nilawati (2018) tentang Audit TI Perusahaan Konsultan Properti Untuk Evaluasi Pengelolaan Data (DS11), Penelitian ini bertujuan untuk evaluasi pengelolaan data pada sistem informasi penyewaan dengan menggunakan Domain Delivery \& Support (DS)-DS11, yang membahas tentang bagaimana mengelola data secara efektif, yaitu dengan melakukan identifikasi kebutuhan data menggunakan kerangka kerja Cobit 4.1. Hasil perhitungan maturity rata-rata memiliki nilai 2.12, yang berarti bahwa kinerja mengolah data pada database berada pada kondisi 2 dapat diulang, artinya proses sudah berkembang, dimana prosedur yang sama dilakukan oleh orang yang berbeda. Belum ada komunikasi atau pelatihan formal atas prosedur standar, dan tanggungjawab diserahkan pada individu. Terdapat kepercayaan yang tinggi pada kemampuan individu, sehingga kesalahan sangat mungkin terjadi. (Nilawati, 2018)

Pada penelitian Jefri Eko Cahyono, Heriyanto, MIM (2013), pemanfaatan Senayan Library Management System (SLiMS) di Kantor Perpustakaan dan Arsip Daerah Kota Salatiga telah memenuhi dua aspek utama dalam teori Technology Acceptance Model (TAM). SLiMS dinilai bermanfaat untuk membantu pekerjaan di perpustakaan termasuk untuk membantu pemustaka dalam proses penelusuran informasi. Pada penelitian ini diketahui pula bahwa pemanfaatan SLiMS belum maksimal dan masih dapat ditingkatkan dengan mengaktifkan visitor counter dan penggunaan fitur copy cataloging yang akan menambah manfaat dari SLiMS. SLiMS merupakan suatu perangkat lunak yang mudah, dalam hal instalasi, modifikasi dan mudah dalam hal pemakaian. (Cahyono \& Heriyanto, 2013)

Pada penellitian Yudho Yudhanto, Ema Utami2, Andi Sunyoto (2018) tentang Audit sistem informasi perpustakaan FMIPA UNS, menghasilkan temuan dan rekomendasi bahwa Sistem Informasi Perpustakaan telah melaksanakan hampir semua aktifitas TI dan mempunyai tingkat kematangan 2.56 yang mempunyai arti bahwa manajemen TI Sistem 
Informasi Perpustakaan FMIPA UNS adalah mendekati Defined Process. Hal ini menunjukkan bahwa aktifitas-aktifitas pada Domain Deliver and Support sudah diterapkan, tetapi belum memiliki prosedur resmi secara tertulis dan terdokumentasi dengan baik. (Yudhanto, 2018)

\section{METODE PENELITIAN}

\subsection{Metode PengambilanData}

Dalam memperoleh data yang tepat dan akurat untuk penelitian yang akan dibuat, maka data atau informasi yang diperoleh adalah dari penelitian secara langsung (data primer) dan secara tidak langsung (data sekunder).

1. Data primer diperoleh secara langsung dengan mengamati kondisi sistem yang sedang berjalan, seperti wawancara, observasi.

2. Data sekunder merupakan data yang dapat digunakan sebagai bahan laporan. Dengan memperoleh data dari studi pustaka.

\subsection{Metode Pengolahan Data}

Data yang didapat adalah data dari hasil penilaian kuesioner secara kualitatif tentang Seanayan Library Management Systems (SLiMS) pada Perpustakaan STIE AUB Surakarta. Data diambil dari responden yang menggunakan atau mengelola operasional pada sistem informasi tersebut, sehingga data dikatakan reliable untuk menggambarkan sistem informasi tersebut.

\subsection{Metode Analisa Data}

Metode yang digunakan dalam penelitian ini bersifat kuantitatif dan deskriptif. Dalam metode kuantitatif menggunakan tingkat kematangan dengan domain Deliver and Support pada proses kontrol Deliver and Support 1(DS1) dan Deliver and Support 11(DS11), sedangkan dalam analisis data menggunakan deskriptif untuk memberikan gambaran kinerja sistem dan rekomendasi yang dibutuhkan.

\subsection{Analis Tingkat Kematangan saat ini (as-is)}

Perhitungan tingkat kematangan saat ini sesuai atribut COBIT 4.1 sesuai dengan rumus (1):

$$
X i=\frac{\sum X a}{\sum r}
$$

Keterangan :

$\mathrm{Xi} \quad=$ nilai kematangan atribut

$\sum X a=$ jumlah nilai tiap atribut

$\sum r \quad=$ jumlah responden

Untuk menghitung nilai kematangan control objective terdapat pada rumus (2)

$$
X_{c o}=\frac{\sum_{6}^{a} X i}{6}
$$

Keterangan :

$X_{\text {co }}=$ nilai tingkat kematangan $\mathrm{CO}$

$\sum X i=$ nilai kematangan atribut

$6=$ jumlah atribut

\subsection{Analisa Tingkat Kematangan yang Diharapkan (to-be)}

Tingkat keamtang yang diharapkan (to-be) pada perusahaan dari skala maturity pihak yang berkaitan menginginkan nilai tingkat kematangan pada level 5 (optimized). 
Perbaikan yang diharapkan dapat meningkatkan tata kelola teknologi informasi sesuai dengan tujuan Perpustakaan STIE AUB Surakarta.

\subsection{Rekomendasi}

Rekomendasi dibuat berdasarkan hasil dari pemetaan tingkat kematangan pada COBIT 4.1. Pada tahap ini bertujuan untuk memberikan gambaran perbaikan yang dibutuhkan perusahaan berdasarkan hasil data yang diperoleh.

\section{HASIL DAN PEMBAHASAN}

Berdasarkan analisa dari kinerja dan tujuan pengelolaan sistem informasi Senayan Library Management Systems (SLiMS) di Perppustakaan STIE AUB Surakarta maka dapat ditentukan proses-proses yang dipilih yaitu DS1 dan DS11 dari Framework COBIT 4.1.

Kemudian menganalisa tingkat kematangan pada sistem informasi Senayan Library Management Systems (SLiMS) menggunakana Framework COBIT 4.1. Proses yang dilakukan yaitu mengumpulkan serta mengolah data yang diperoleh dari wawancara dan penyebaran kuesioner kepada pihak pengelola sistem atau staff dan mahasiswa STIE AUB Surakarta. Responden ditentukan berdasarkan tabel RACI Chart yang berjumlah 40 orang.

Pembuatan kueisoner ini bertujuan untuk mendapatkan suatu gambaran mengenai sistem informasi lebih cepat dan menyeluruh dalam bentuk angket pertanyaan kepada responden. Terdapat 72 butir pertanyaan dari 36 butir pertanyaan sesuai dengan DS1 (Delieve and Support 1) dan DS11 (Delieve and Support 11).

Perhitungan tingkat kematangan (maturity level) berdasarkan data dari kueioner yang telah diisi oleh responden. Dari data kuesioner tersebut akan diolah menjadi data kuantitantif (angka) sehingga dapat diperoleh data hasil akhir yang akan dimasukkan ke dalam penilaian standar skala maturity level COBIT 4.1. Maturity level untuk masingmasing Control Objective dengan mengacu nilai kematangan atribut Cobit. Seperti pada Tabel 1 dan Tabel 2.

Tabel 1. hasil perhitungan tingkat kematangan sub domain DS1 kategori pengelola.

\begin{tabular}{|c|c|c|c|}
\hline $\begin{array}{c}\text { Control Objective } \\
(\text { CO })\end{array}$ & Atribut & $\begin{array}{c}\text { Nilai Kematangan } \\
\text { Atribut }\end{array}$ & Nilai Kematangan (CO) \\
\hline \multirow{6}{*}{ DS1.1 } & $\mathrm{AC}$ & 2,75 & \multirow{6}{*}{2,79} \\
\hline & PSP & 3,25 & \\
\hline & TA & 2,75 & \\
\hline & $\mathrm{SE}$ & 2,75 & \\
\hline & $\mathrm{RA}$ & 3 & \\
\hline & GSM & 2,25 & \\
\hline \multirow{6}{*}{ DS1.2 } & $\mathrm{AC}$ & 2,87 & \multirow{6}{*}{2,79} \\
\hline & PSP & 2,37 & \\
\hline & TA & 2,75 & \\
\hline & SE & 3 & \\
\hline & RA & 3,12 & \\
\hline & GSM & 2,62 & \\
\hline \multirow{6}{*}{ DS1.3 } & $\mathrm{AC}$ & 2,65 & \multirow{6}{*}{2,79} \\
\hline & PSP & 2,87 & \\
\hline & TA & 2,87 & \\
\hline & SE & 2,87 & \\
\hline & RA & 3,12 & \\
\hline & GSM & 2,37 & \\
\hline
\end{tabular}


Tabel 1. Hasil perhitungan tingkat kematangan sub domain DS1 kategori pengelola. (Lanjutan)

\begin{tabular}{|c|c|c|c|}
\hline $\begin{array}{c}\text { Control Objective } \\
(C O)\end{array}$ & $\overline{\text { Atribut }}$ & $\begin{array}{c}\text { Nilai Kematangan } \\
\text { Atribut }\end{array}$ & Nilai Kematangan (CO) \\
\hline \multirow{6}{*}{ DS1.4 } & $\mathrm{AC}$ & 2,87 & \multirow{6}{*}{2,91} \\
\hline & $\begin{array}{l}\text { PSP } \\
\end{array}$ & 2,62 & \\
\hline & TA & 3,12 & \\
\hline & SE & 2,75 & \\
\hline & RA & 3,37 & \\
\hline & GSM & 2,75 & \\
\hline \multirow{6}{*}{ DS1.5 } & $\mathrm{AC}$ & 3 & \multirow{6}{*}{2,77} \\
\hline & PSP & 2,5 & \\
\hline & TA & 2,87 & \\
\hline & SE & 2,62 & \\
\hline & RA & 3,12 & \\
\hline & GSM & 2,5 & \\
\hline \multirow{7}{*}{ DS1.6 } & $\mathrm{AC}$ & 2,75 & \multirow{6}{*}{2,89} \\
\hline & $\begin{array}{l}\text { PSP } \\
\end{array}$ & 2,37 & \\
\hline & TA & 2,87 & \\
\hline & SE & 3,12 & \\
\hline & RA & 3,37 & \\
\hline & GSM & 2,87 & \\
\hline & \multicolumn{2}{|c|}{ Rata-rata } & 2,82 \\
\hline
\end{tabular}

Tabel 2. Hasil perhitungan tingkat kematangan sub domain DS1 kategori mahasiswa.

\begin{tabular}{|c|c|c|c|}
\hline $\begin{array}{c}\text { Control } \\
\text { Objective }(\mathrm{CO})\end{array}$ & Atribut & $\begin{array}{c}\text { Nilai } \\
\text { Kematangan } \\
\text { Atribut } \\
\end{array}$ & $\begin{array}{c}\text { Nilai Kematangan } \\
\text { CO }\end{array}$ \\
\hline \multirow{6}{*}{ DS1.1 } & 1 & 3,03 & \multirow{6}{*}{3,14} \\
\hline & 2 & 3,31 & \\
\hline & 3 & 2,81 & \\
\hline & 4 & 3,03 & \\
\hline & 5 & 3,37 & \\
\hline & 6 & 3,31 & \\
\hline \multirow{6}{*}{ DS1.2 } & 1 & 3,12 & \multirow{6}{*}{3,19} \\
\hline & 2 & 3,15 & \\
\hline & 3 & 3,03 & \\
\hline & 4 & 3,06 & \\
\hline & 5 & 3,34 & \\
\hline & 6 & 3,43 & \\
\hline \multirow{6}{*}{ DS1.3 } & 1 & 3,46 & \multirow{6}{*}{3,29} \\
\hline & 2 & 3,5 & \\
\hline & 3 & 3,21 & \\
\hline & 4 & 3,03 & \\
\hline & 5 & 3,28 & \\
\hline & 6 & 3,25 & \\
\hline
\end{tabular}


Tabel 2. Hasil perhitungan tingkat kematangan sub domain DS1 kategori mahasiswa (Lanjutan)

\begin{tabular}{|c|c|c|c|}
\hline $\begin{array}{c}\text { Control } \\
\text { Objective }(\mathrm{CO})\end{array}$ & Atribut & $\begin{array}{c}\text { Nilai } \\
\text { Kematangan } \\
\text { Atribut }\end{array}$ & $\begin{array}{c}\text { Nilai Kematangan } \\
\text { CO }\end{array}$ \\
\hline \multirow{6}{*}{ DS1.4 } & 1 & 2,81 & \multirow{6}{*}{3,18} \\
\hline & 2 & 3,15 & \\
\hline & 3 & 2,98 & \\
\hline & 4 & 3,43 & \\
\hline & 5 & 3,53 & \\
\hline & 6 & 3,18 & \\
\hline \multirow{6}{*}{ DS 1.5} & 1 & 3,09 & \multirow{6}{*}{3,10} \\
\hline & 2 & 3,28 & \\
\hline & 3 & 3,09 & \\
\hline & 4 & 3,06 & \\
\hline & 5 & 3,09 & \\
\hline & 6 & 3 & \\
\hline \multirow{6}{*}{ DS1.6 } & 1 & 3,09 & \multirow{6}{*}{3,20} \\
\hline & 2 & 3,12 & \\
\hline & 3 & 3,43 & \\
\hline & 4 & 3,12 & \\
\hline & 5 & 3,37 & \\
\hline & 6 & 3,06 & \\
\hline & \multicolumn{2}{|c|}{ Rata-rata } & 3,18 \\
\hline
\end{tabular}

Pada Tabel 3 dan Tabel 4 adalah perhitungan tingkat kematangan berdasarkan sub domain DS11.

Tabel 3. Hasil perhitungan tingkat kematangan sub domain DS11 kategori pengelola

\begin{tabular}{|c|c|c|c|}
\hline $\begin{array}{c}\text { Control Objective } \\
(C O)\end{array}$ & Atribut & $\begin{array}{c}\text { Nilai Kematangan } \\
\text { Atribut }\end{array}$ & $\begin{array}{c}\text { Nilai Kematangan } \\
\text { CO }\end{array}$ \\
\hline \multirow{6}{*}{ DS11.1 } & 1 & 2,62 & \multirow{6}{*}{ 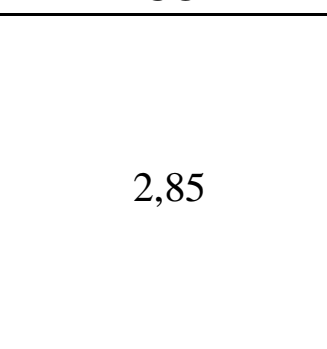 } \\
\hline & 2 & 2,87 & \\
\hline & 3 & 3 & \\
\hline & 4 & 2,75 & \\
\hline & 5 & 3,25 & \\
\hline & 6 & 2,62 & \\
\hline \multirow{6}{*}{ DS11.2 } & 1 & 3,12 & \multirow{6}{*}{2,95} \\
\hline & 2 & 2,87 & \\
\hline & 3 & 3 & \\
\hline & 4 & 2,62 & \\
\hline & 5 & 3,37 & \\
\hline & 6 & 2,75 & \\
\hline
\end{tabular}


Tabel 3. Hasil perhitungan tingkat kematangan sub domain DS11 kategori pengelola (Lanjutan)

\begin{tabular}{|c|c|c|c|}
\hline $\begin{array}{c}\text { Control Objective } \\
\text { (CO) }\end{array}$ & Atribut & $\begin{array}{c}\text { Nilai Kematangan } \\
\text { Atribut }\end{array}$ & $\begin{array}{c}\text { Nilai Kematangan } \\
\text { CO }\end{array}$ \\
\hline \multirow{6}{*}{ DS11.3 } & 1 & 3,25 & \multirow{6}{*}{2,97} \\
\hline & 2 & 2,62 & \\
\hline & 3 & 2,62 & \\
\hline & 4 & 3,12 & \\
\hline & 5 & 3,25 & \\
\hline & 6 & 3 & \\
\hline \multirow{6}{*}{ DS11.4 } & 1 & 3,12 & \multirow{6}{*}{2,93} \\
\hline & 2 & 2,87 & \\
\hline & 3 & 2,62 & \\
\hline & 4 & 2,87 & \\
\hline & 5 & 3,12 & \\
\hline & 6 & 3 & \\
\hline \multirow{6}{*}{ DS11.5 } & 1 & 3,37 & \multirow{6}{*}{3} \\
\hline & 2 & 3 & \\
\hline & 3 & 3 & \\
\hline & 4 & 2,75 & \\
\hline & 5 & 3,12 & \\
\hline & 6 & 2,75 & \\
\hline \multirow{6}{*}{ DS11.6 } & 1 & 3,12 & \multirow{6}{*}{3,06} \\
\hline & 2 & 3 & \\
\hline & 3 & 3,12 & \\
\hline & 4 & 3 & \\
\hline & 5 & 3,37 & \\
\hline & 6 & 2,75 & \\
\hline & \multicolumn{2}{|c|}{ Rata-rata } & 2,96 \\
\hline
\end{tabular}

Tabel 4. Hasil perhitungan tingkat kematangan sub domain DS11 kategori mahasiswa

\begin{tabular}{|c|c|c|c|}
\hline $\begin{array}{c}\text { Control } \\
\text { Objective }(\mathrm{CO})\end{array}$ & Atribut & $\begin{array}{c}\text { Nilai Kematangan } \\
\text { Atribut }\end{array}$ & $\begin{array}{c}\text { Nilai Kematangan } \\
\text { CO }\end{array}$ \\
\hline \multirow{6}{*}{ DS11.1 } & 1 & 3,40 & \multirow{6}{*}{+} \\
\hline & 2 & 3,31 & \\
\hline & 3 & 3,28 & \\
\hline & 4 & 3,40 & \\
\hline & 5 & 3,53 & \\
\hline & 6 & 3,21 & \\
\hline \multirow{6}{*}{ DS11.2 } & 1 & 3,21 & \multirow{6}{*}{3,25} \\
\hline & 2 & 3,12 & \\
\hline & 3 & 3,25 & \\
\hline & 4 & 3,46 & \\
\hline & 5 & 3,25 & \\
\hline & 6 & 3,18 & \\
\hline
\end{tabular}


Tabel 4. Hasil perhitungan tingkat kematangan sub domain DS11 kategori mahasiswa (Lanjutan)

\begin{tabular}{|c|c|c|c|}
\hline $\begin{array}{c}\text { Control } \\
\text { Objective (CO) }\end{array}$ & Atribut & $\begin{array}{c}\text { Nilai Kematangan } \\
\text { Atribut }\end{array}$ & $\begin{array}{c}\text { Nilai Kematangan } \\
\text { CO }\end{array}$ \\
\hline \multirow{6}{*}{ DS 11.3} & 1 & 3,25 & \multirow{6}{*}{3,22} \\
\hline & 2 & 2,87 & \\
\hline & 3 & 3,56 & \\
\hline & 4 & 3,34 & \\
\hline & 5 & 3,25 & \\
\hline & 6 & 3,09 & \\
\hline \multirow[t]{6}{*}{ DS11.4 } & 1 & 3,31 & 3,28 \\
\hline & 2 & 3,34 & \\
\hline & 3 & 3,21 & \\
\hline & 4 & 3,40 & \\
\hline & 5 & 3,15 & \\
\hline & 6 & 3,28 & \\
\hline \multirow{6}{*}{ DS11.5 } & 1 & 3,31 & \multirow{6}{*}{3,40} \\
\hline & 2 & 3,5 & \\
\hline & 3 & 3,43 & \\
\hline & 4 & 3,28 & \\
\hline & 5 & 3,46 & \\
\hline & 6 & 3,40 & \\
\hline \multirow[t]{7}{*}{ DS11.6 } & 1 & 3,31 & 3,25 \\
\hline & 2 & 3,5 & \\
\hline & 3 & 3,12 & \\
\hline & 4 & 3,34 & \\
\hline & 5 & 3,15 & \\
\hline & 6 & 3,06 & \\
\hline & \multicolumn{2}{|c|}{ Rata-rata } & 3,29 \\
\hline
\end{tabular}

Grafik Nilai Kematangan

a. Grafik Nilai Kematangan (Current Maturity Level) DS1

NILAI MATURITY LEVEL DELIVER AND SUPPORT 1

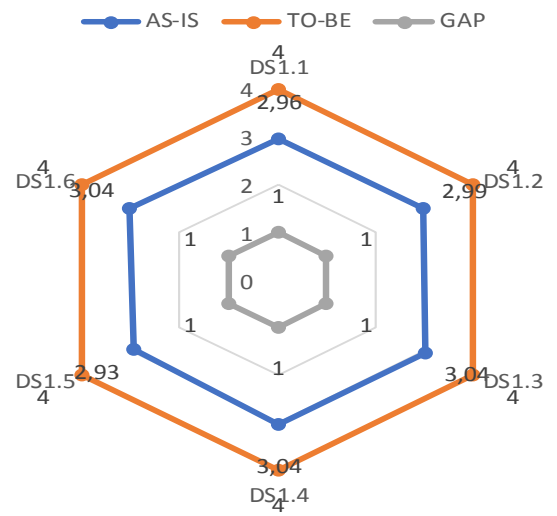

Gambar 2. Grafik CML DS1 
b. Grafik Nilai Kematangan (Current Maturity Level) DS11

\section{NILAI MATURITY LEVEL DELIVER AND SUPPORT11}

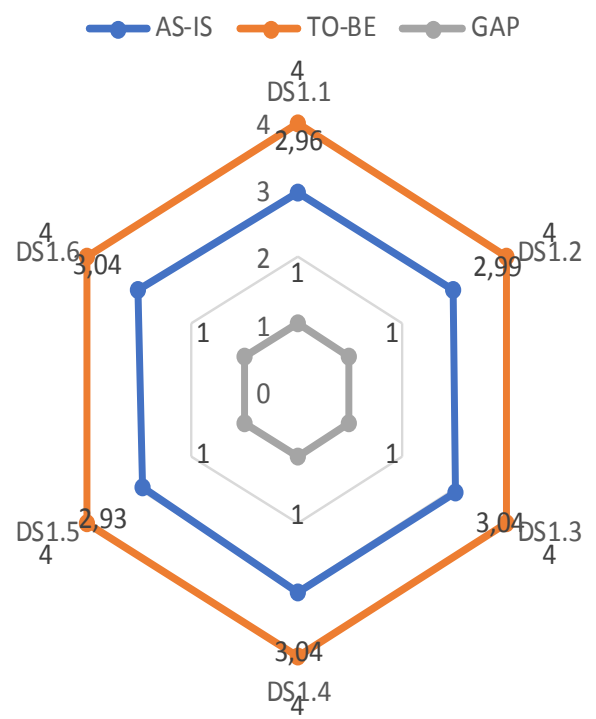

Gambar 3, Grafik CML DS11

Tabel 5 merupakan skala indeks penilaian tingkat kematangan (Maturity Level) :

Tabel 5. Skala indeks tingkat kematangan (maturity level)

\begin{tabular}{|l|l|}
\hline $\begin{array}{c}\text { Nilai } \\
\text { Kematangan }\end{array}$ & \multicolumn{1}{c|}{ Tingkat Kematangan } \\
\hline $0.0-0.50$ & $0-$ Non-Exixtent \\
\hline $0.51-1.50$ & $1-$ Initial/ Ad Hoc \\
\hline $1.51-2.50$ & $2-$ Repeatable but intuitif \\
\hline $2.51-3.50$ & $3-$ Define \\
\hline $3.51-4.50$ & $4-$ Manage and Measurable \\
\hline $4.51-5.00$ & $5-$ Optimized \\
\hline
\end{tabular}

Berada pada level 3 sesuai standar tingkat kematangan dari Framework COBIT 4.1 yaitu kondisi dimana manajemen perusahaan telah memiliki prosedur baku formal dan tertulis. Prosedur tersebut telah disosialisasikan kepada seluruh manajemen dan staff serta telah dipatuhi dan dikerjaan dalam aktivitas sehari-hari.

Tingkat harapan kematangan pada proses evaluasi sistem merupakan kondisi ideal pada tingkat kematangan yang diharapkan oleh instansi atau perpusahaan, yang akan menjadi acuan pengembangan Senayan Library Management Systems (SLiMS) di Perpustakana STIE AUB Surakarta. Tingkat harapan ditentukan dengan melihat lingkungan internal dari Perpustakaan STIE AUB Surakarta misalnya Visi, Misi dan Tujuan Perpustakaan STIE AUB Surkarta. Maka ditetapkan tingkat kematangan yang diharapkan berada pada level 4 (Manage and Measurable).

Setelah nilai tingkat kematangan ditentukan maka dicari nilai kesenjangan (gap analisys), yaitu perhitungan selisih antara nilai kematangan yang diharapkan (to-be) 
dengan nilai kematangan saat ini (as-is). Tingkat kesenjangan seperti pada Tabel 8 dan Tabel 9.

Tabel 8 Tingkat kesenjangan (gap) DS1

\begin{tabular}{|c|c|c|c|}
\hline \multirow{2}{*}{$\begin{array}{c}\text { Control } \\
\text { Objectives }\end{array}$} & \multicolumn{3}{|c|}{ Tingkat Kematangan } \\
\cline { 2 - 4 } & $\boldsymbol{a s}-\boldsymbol{i s}$ & to-be & gap \\
\hline DS1.1 & 3 & 4 & 1 \\
\hline DS1.2 & 3 & 4 & 1 \\
\hline DS1.3 & 3 & 4 & 1 \\
\hline DS1.4 & 3 & 4 & 1 \\
\hline DS1.5 & 3 & 4 & 1 \\
\hline DS1.6 & 3 & 4 & 1 \\
\hline
\end{tabular}

Tabel 9 Tingkat Kesenjangan (gap) DS11

\begin{tabular}{|c|c|c|c|}
\hline \multirow{2}{*}{$\begin{array}{c}\text { Control } \\
\text { Objectives }\end{array}$} & \multicolumn{3}{|c|}{ Tingkat Kematangan } \\
\cline { 2 - 4 } & as-is & to-be & gap \\
\hline DS11.1 & 3 & 4 & 1 \\
\hline DS11.2 & 3 & 4 & 1 \\
\hline DS11.3 & 3 & 4 & 1 \\
\hline DS11.4 & 3 & 4 & 1 \\
\hline DS11.5 & 3 & 4 & 1 \\
\hline DS11.6 & 3 & 4 & 1 \\
\hline
\end{tabular}

Evaluasi sistem informasi Senayan Library Management Systems (SLiMS) di Perpustakaan STIE AUB Surakarta menggunakan domain Delivery and Support Framework COBIT 4.1 khususnya pada subdomain DS1 (Menetapkan dan Mengelola Tingkat Layanan) dan DS11 (Mengelola Data) menghasilkan rekomendasi akhir sebagai putusan dari identifikasi masalah sistem yang terjadi serta pengambilan rumusan rekomendasi perbaikan. dan menghasilkan aplikasi perhitungan maturity level sebagai berikut :

1. Tampilan menu login.

Menu login seperti pada Gambar 4, dapat dijalankan sebagai admin, responden pengelola dan responden mahasiswa.

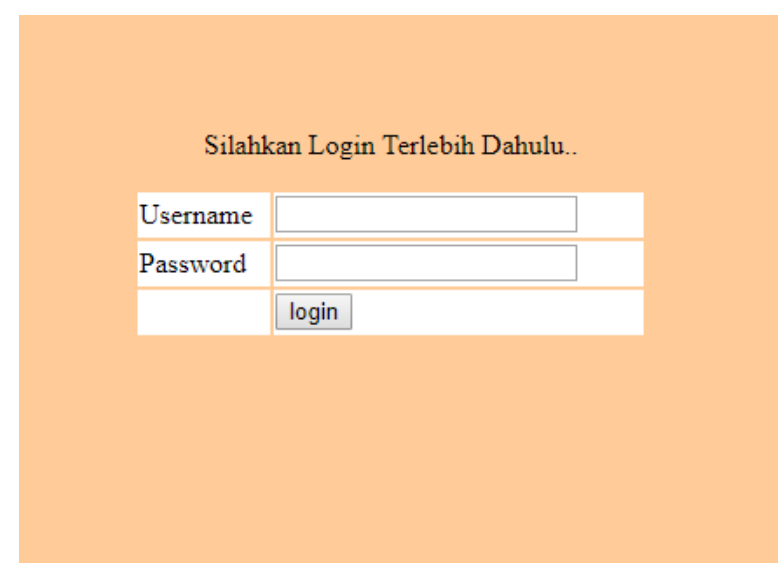

Gambar 4. Tampilan menu login 
2. Tampilan menu pertanyaan kuesioner.

Pada menu pertanyaan kuesioner seperti pada Gambar 5, responden dapat menjawab pertanyaan yang sudah disediakan oleh admin.

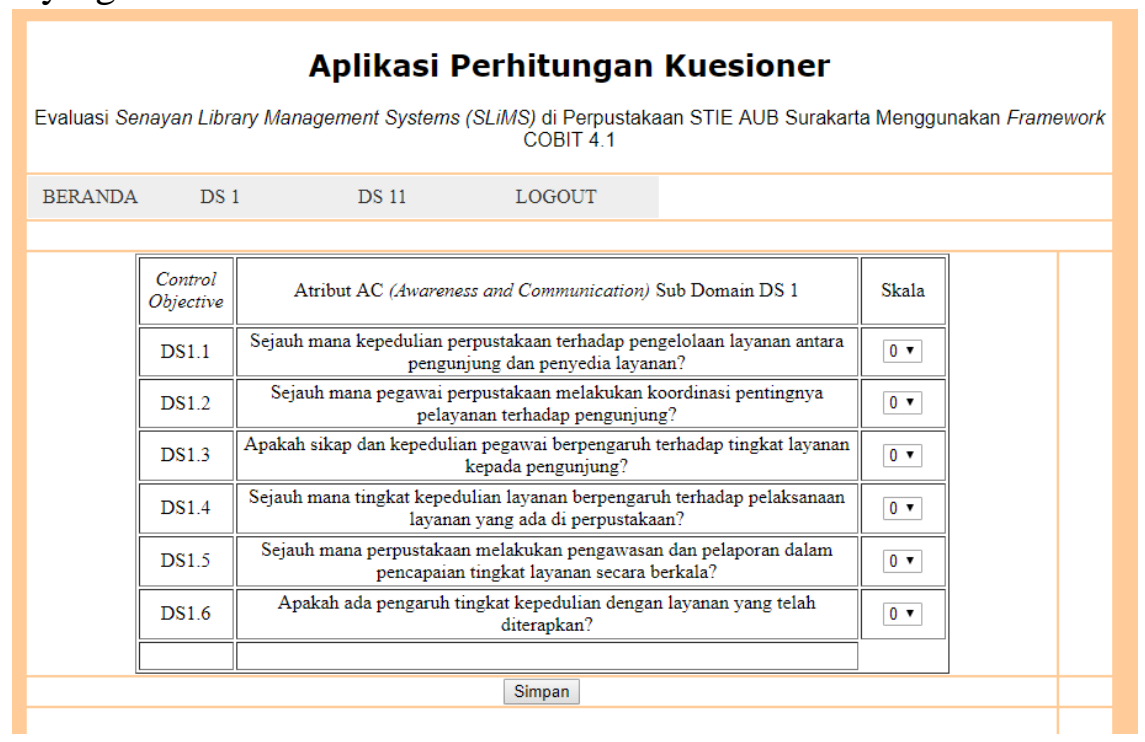

Gambar 5. Tampilan menu pertanyaan

3. Menu proses perhitungan.

Menu proses perhitungan seperti pada Gambar 6 merupakan tampilan dari hasil jawaban yang sudah di isi oleh responden baik pengelola maupun mahasiswa dan hanya dapat dilihat oleh admin.

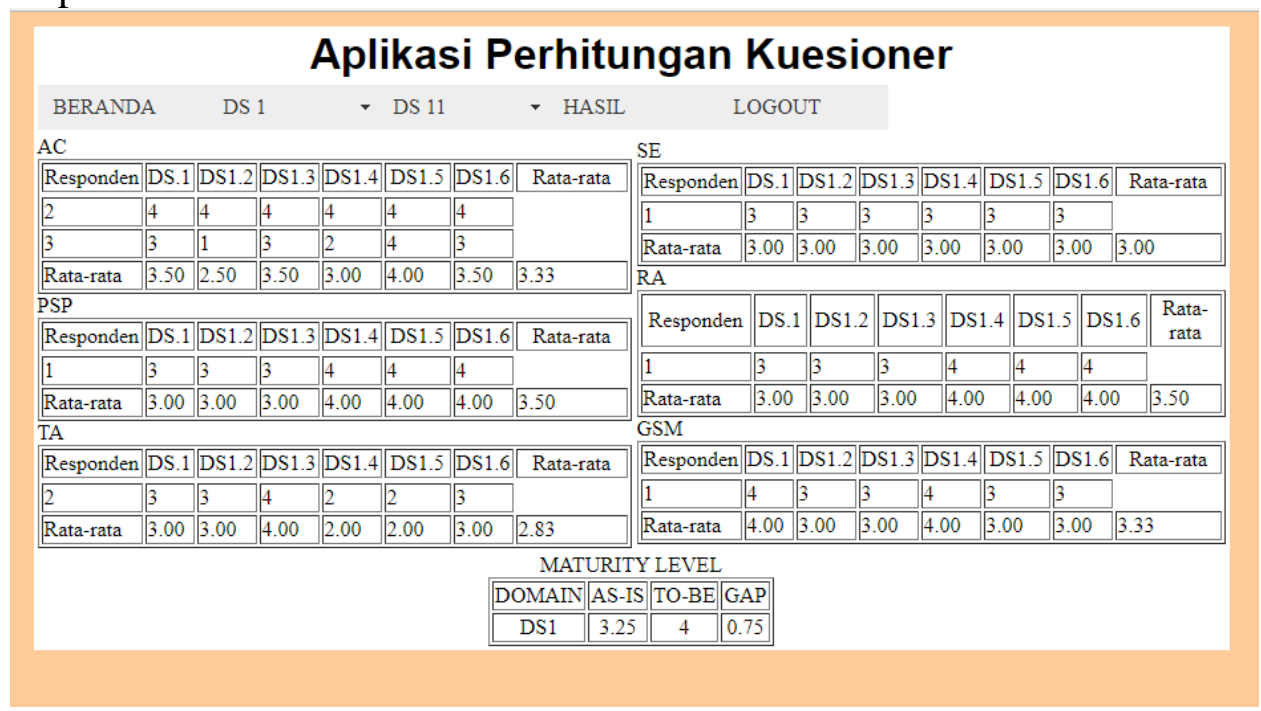

Gambar 6. Menu proses perhitungan

4. Menu grafik.

Pada Gambar 7 digunakan untuk menampilkan grafik hasil akhir proses perhitungan. 


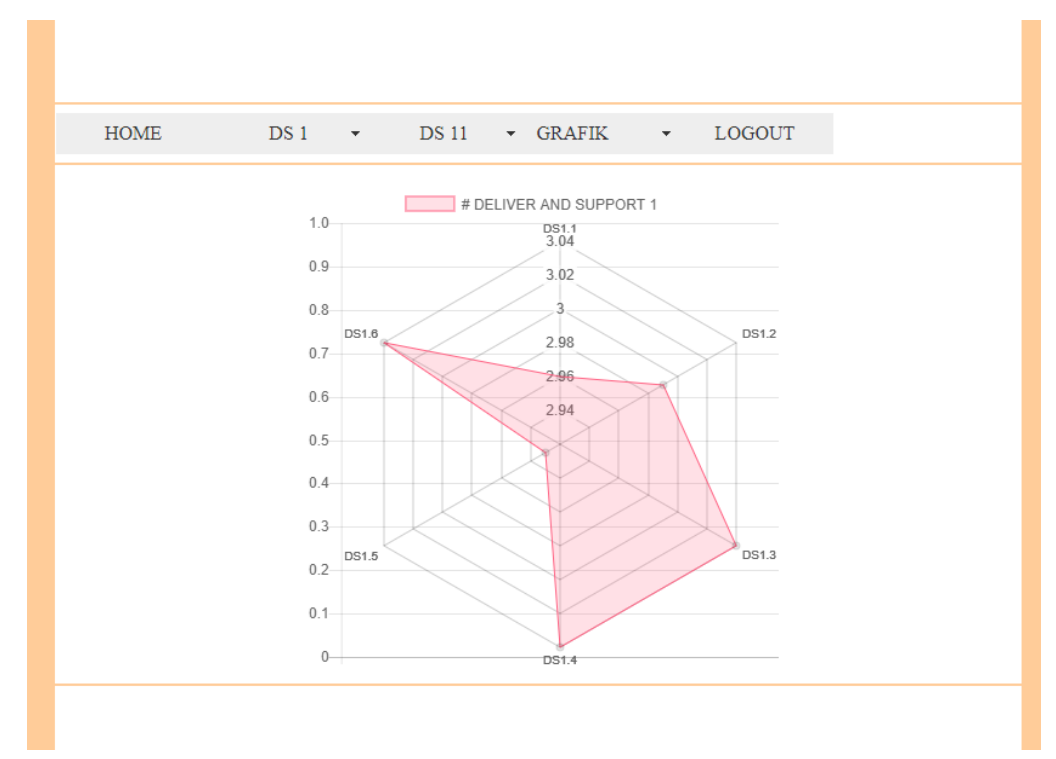

Gambar 7. Menu proses perhitungan

\section{PENUTUP}

\subsection{Kesimpulan}

Berdasarkan dari hasil penelitian dengan judul Evaluasi Senayan Library Management Systems (SLiMS) Pada Perpustakaan STIE AUB Surakarta Menggunakan Framework COBIT 4.1 maka dapat diambil kesimpulan

1. Pelaksanaan analisis Control Objective dilakukan dengan cara menganalisa permasalahan yang ada pada Senayan Library Management Systems (SLiMS) Perpustakaan STIE AUB Surakarta kemudian menentukan Control Objective dan dilakukan perhitungan dengan tingkat kematangan secara keseluruhan terhadap domain DS1, dan DS11.

2. Hasil maturity level pada domain Deliver and Support (DS1) adalah 3 dengan tingkat maturity level berada pada level 3

3. Hasil maturity level pada domain Deliver and Support (DS11) adalah 3,11 dengan maturity level berada pada level 3

4. Tingkat harapan penggunaan Senayan Library Management Systems (SLiMS) sebesar 4 dengan tingkat maturity level yaitu terukur dan ditetapkan (managed and measurable).

5. Rekomendasi penelitian ini dibuat berdasarkan masalah yang diidentifikasikan menurut 6 proses sub domain DS1 (menetapkan dan mengelola tingkat layanan), 6 proses sub domain DS11 (menegelola data) serta menggunakan kuesioner berdasarkan 6 atribut informasi. Ringkasan rekomendasi dihasilkan 8 rekomendasi akhir yang memiliki kesamaan nilai hitam. Rekomendasi tersebut antara lain yaitu mengadakan koordinasi guna meningkatkan kualitas kinerja sistem dan pelayanan sistem, melakukan pengawasan dan pemantauan terhadap sistem, melakukan pemasangan alat bantu dan pemeliharaan sebagai keamanan sistem, pemberlakuan keterampilan dan pelatihan secara berkelanjutan, pengukuran pencapaian tujuan bisnis dan menformalkan kepada seluruh devisi perpustakaan. 


\subsection{Saran}

Mengenai evaluasi pengelolaan Senayan Library Management Systems (SLiMS), maka penulis memberikan saran sebagai berikut :

1. Diharapkan perpustakaan mengimplementasikan seluruh hasil rekomendasi dari penelitian menggunakan framework COBIT 4.1 keseluruh bagian yang berkaitan dengan proses pelayanan dan pengelolaan data perpustakaan.

2. Untuk peneltian selanjutnya dapat berfokus pada semua domain pada COBIT 4.1 dan melakukan evaluasi keseluruh manajemen pada Perpustakaan STIE AUB Surakarta.

3. Diharapkan tersusunnya penelitian evaluasi sistem Senayan Library Management Systems (SLiMS) dapat dilakukan perbaikan dengan membangun koordinasi antara kepala perpustakaan dan staff perpustakaan untuk menjadikan hasil analisa penelitian ini sebagai perbaikan pada Perpustakaan STIE AUB Surakarta.

\section{DAFTAR PUSTAKA}

Azwar, M. (2013). Membangun Sistem Otomasi Perpustakaan dengan Senayan Library Management Sistems ( SLiMS ). Khizanah Al-Hikmah, 1(1), 19-33. Retrieved from http//journal.uin-alauddin.ac.id/index.php/khizanah-al-hikmah/article/view/23

Cahyono, J. E., \& Heriyanto, H. (2013). Analisis Pemanfaatan Senayan Library Management System (SLiMS) di Kantor Perpustakaan dan Arsip Daerah Kota Salatiga. Jurnal Ilmu Perpustakaan, 2(3), 139-152. https://doi.org/10.1016/j.geoderma.2012.09.001

Juliandarini, \& Handayaningsih, S. (2013). Audit Sistem Informasi Pada Digilib Universitas XYZ Menggunakan Kerangka Kerja Cobit 4.0. Jurnal Sarjana Teknik Informatika, 1(1), 276-286.

Meadwos Rolling. (2007). Cobit 4.1 Framework Control Objectives Management Guidelines Maturity Models. Governance An International Journal Of Policy And Administration. https://doi.org/10.1016/S0167-4048(97)84675-5.

Nilawati, L. (2018). Audit TI Perusahaan Konsultan Properti Untuk Evaluasi Pengelolaan data (DS11). Jurnal Informatika, 5(1), 119-127. https://doi.org/10.1007/978-1-49397717-8_6

Satyareni, D. H., \& Mahanani, F. (2014). Audit Sistem Informasi Akademik Perguruan Tinggi (PT) XYZ Menggunakan Kerangka Kerja COBIT 4.1. Seminar Nasional Aplikasi Teknologi Informasi (SNATI) Yogyakarta, 21(1), 1907-5022.

Yudhanto, Y, Utami, E., \& Sanyoto, A. (2018). Audit Sistem Informasi Perpustakaan FMIPA UNS. In Seminar Nasional Teknologi Informasi dan Multimedia 2018 (pp. 16). Yogyakarta: Universitas AMIKOM Yogyakarta. 